\title{
PEMBERIAN REMISI TERHADAP PELAKU TINDAK PIDANA KORUPSI DALAM PRESPEKTIF HUKUM POSITIF
}

Oleh :

\author{
Didit Prihantoro ${ }^{1}$
}

\begin{abstract}
Abstraksi
Dalam memberikan remisi terhadap narapidana tindak pidana korupsi diberlakukan suatu pengetatan untuk memperoleh remisi. Pemberian remisi yang diperketat ini kenyataannya masih mendapatkan pro dan kontra bagi beberapa pihak. Oleh karena itu tujuan dari penulisan ini yaitu guna mengetahui bahwa syarat pemberian remisi yang terkandung dalam PP No. 99 Tahun 2012 kemudian dikaitkan dengan UU No. 12 Tahun 1995 Tentang Permasyarakatan, serta apakah Peraturan Pemerintah tersebut sesuai atau tidak dengan Teori Tujuan Pemidanaan. Penelitian ini memakai metode yuridis normatif, sedangkan pendekatan yang dipergunakan dalam penelitian ini yaitu pendekatan analisis konsep hukum dan The Statute Approach. Adapun hasil yang diperoleh dari adanya penelitian ini yaitu syarat akan pemberian remisi bagi tindak pidana korupsi yang terdapat dalam PP No. 99 Tahun 2012 menurut hierarki perundang-undangan yang ada di Indonesia bertentangan dengan UU. No. 12 Tahun 1995 Tentang Permasyarakatan. Dan sampai sekarang masih terdapat dua pendapat mengenai kesesuaian dalam Teori Tujuan Pemidanaan.
\end{abstract}

Kata Kunci : Korupsi, Remisi, Undang-Undang

\section{Latar Belakang}

Di negara Indonesia, masih banyak praktek korupsi yang terjadi di semua lini, baik dalam kalangan legislatif, eksekutif, pusat maupun di daerah. Korupsi telah mengakar pada masyarakat Indonesia sehingga menjadi budaya yang sulit untuk dihilangkan. ${ }^{2}$ Masalah korupsi yang terjadi di negara ini dapat ditemukan dalam segala bidang kehidupan pemerintahan dan sosial, korupsi menjadi sebuah virus yang menyebar sampai kesektor swasta sampai ke tingkat RT yang sudah sangat jelas bahwa dengan adanya korupsi ini akan menimbulkan kerugian yang sangat besar. Sebenarnya jika dilihat secara lebih teliti, adanya praktek korupsi yang terjadi tidak pernah berkurang dan justru bertambah ini menunjukkan bahwasanya 
kurangnya ketegasan dan tidak konsistennya dalam menerapkan peratutan perundang-undangan.

Di Indonesia, diperlukannya aturan yang majemuk mengenai hukum sehingga diharapkan bisa menciptakan sebuah keadilan bagi seluruh masyarakat yang ada di Indonesia, karena pada hakekatnya tujuan dari negara ini yang harus dicapai yaitu ketertiban, keadilan, dan kemakmuran dan kedamaian untuk hidup saling berdampingan.

Remisi diberikan kepada para narapidana yang pada mulanya diatur dalam PP No. 28 Tahun 2006 akan tetapi dengan diberlakukannya peraturan tersebut menimbulkan pro dan kontra karena menurut pandangan masyarakat korupsi merupakan kejahatan yang sangat merugikan negara, keuangan negara, dan masyarakat sehingga dengan pemberian remisi yang mudah didapat oleh narapidana korupsi dianggap sesuatu yang tidak adil. Hal tersebut tidaklah omong kosong belaka karena jika dilihat kebelakang banyak koruptor yang menikmati remisi dengan sangat mudah misalnya saja kasus narapidana Urip yang divonis 20 tahun penjara serta dendan 500 juta mendapatkan remisi dengan sangat mudah sebesar satu bulan lamanya, serta remisi umum pada hari kemerdekaan selama empat bulan lamanya. Keputusan dalam pemberian remisi tersebut dinilai sangat berlebihan, terkesan koruptor sangat di istimewakan. Koruptor telah mencuri uang negara dengan jumlah yang sangat besar sehingga seharusnya para koruptor harus segera dimiskinkan tanpa menikmati keistimewaan termasuk menerima remisi dengan mudah.

Tindak pidana korupsi merupakan kejahatan yang luar biasa atau extra ordinary sehingga dalam pemberantasannya juga harus diperlukan suatu usaha yang sangat besar termasuk dengan membebaskan dari adanya praktik menyimpang dalam memberikan remisi,pemberian remisi haruslah diperketat. Perubahan dalam pengaturan mengenai syarat penerimaan remisi memang harus dilakukan. Remisi yang didapatkan oleh narapidana dengan kasus korupsi besarannya harus berbeda dengan remisi yang diperoleh oleh narapidana biasa. Dalam memperoleh remisi, seorang narapidana harus memiliki persyaratan yang harus dipenuhi. Jika dilihat dari kebijakan perundang-undangan mengenai remisi 
maka untuk memperolehnya narapidana harus berkelakuan baik dan mematuhi segala peraturan yang ada dalam Lembaga Permasyarakatan.

Banyaknya masyarakat yang menganggap pemberian remisi merupakan suatu ketidakadilan maka pemerintah mengeluatkan PP No. 99 Tahun 2012 Tentang Perubahan Kedua Atas Peraturan Pemerintah No. 32 Tahun 1999 Tentang Syarat Dan Tata Cara Pelaksanaan Hak Warga Binaan Pemasyarakatan. Kemudian terdapat penambahan aturan megenai syarat dalam pemberian remisi kepada narapidana korupsi yang lebih diperketat, diatur dalam Pasal 34 angka (1). Hal tersebut dilakukan oleh pemerintah agar menciptakan keadilan bagi masyarakat. Namun tetap saja, pro kontra mengenai suatu peraturan masihlah muncul, berapa kalangan menyampaikan bahwa PP No. 99 Tahun 2012 bertentangan dengan UU Tentang Permasyarakatan. Permasalahan mengenai kesesuaian pemberian remisi terhadap koruptor yang terdapat pada pasal Pasal 34 PP No. 99 Tahun 2012 juga ikut dipertanyakan. Sesuai dengan permasalahan yang ada maka penelitian ini mengambil judul Pemberian Remisi Terhadap Pelaku Tindak Pidana Korupsi Dalam Prespektif Hukum Positif.

\section{Rumusan Masalah}

Sesuai dengan latar belakang yang ada, maka rumusan masalah yang diambil pada penelitian ini yaitu :

2.1 Bagaimana syarat pemberian remisi terhadap pelaku tindak pidana korupsi yang diatur dalam PP No. 99 Tahun 2012 yang dikaitkan dengan UU No. 12 Tahun 1995 Tentang Permasyarakatan?

2.2 Bagaimana pemberian remisi yang diatur dalam PP No. 99 Tahun 2012 yang dikaitkan dengan Teori Tujuan Pemidanaan?

\section{Tujuan Penelitian}

Adapun tujuan yang hendak dicapai dalam penelitian ini adalah:

3.1 Untuk mengetahui syarat pemberian remisi terhadap pelaku tindak pidana korupsi yang diatur dalam PP No. 99 Tahun 2012 yang dikaitkan dengan UU No. 12 Tahun 1995 Tentang Permasyarakatan. 
3.2 Untuk mengetahui pemberian remisi yang diatur dalam PP No. 99 Tahun 2012 yang dikaitkan dengan Teori Tujuan Pemidanaan.

\section{Manfaat Penelitian}

Hasil Penelitian ini, secara teoritis maupun praktis diharapkan dapat memberikan manfaat bagi akademisi atau peneliti hukum untuk mengembangkan ilmu pengetahuan dibidang hukum pidana khususnya aspek-aspek yang terkait dalam pengaturan tindak pidana korupsi.

\section{Metode Penelitian}

Merujuk pada rumusan masalah yang digunakan maka penelitian ini menggunakan metode penelitian hukum yuridis normatif yang dalam artian bahwa dalam melakukan penelitiannya dengan meneliti data sekunder atau bahan pustaka, mencakup penelitian yang dilakukan pada sinkronisasi hukum, asas-asas hukum, perbandingan hukum, dan sistematika hukum. ${ }^{3}$ Penelitian ini memakai metode normatif sebagai pendekatan utama karena pokok dari tujuan diadakannya penelitian ini yaitu untuk mengetahui syarat pemberian remisi yang diberikan kepada narapidana yang kemudian dikaitkan dengan UU Tentang Permasyarakatan sehingga ketentuan perundang-undanglah yang mengaturnya. Sedangkan dalam pendekatannya menggunakan jenis pendekatan peraturan perundang-undangan atau The Statute Approach dan pendekan analisis konsep hukum atau Analitical \& Conseptual Approach.

Penelitian ini menggunakan bahan hukum atau bahan pustaka yang meliputi:

1. Bahan hukum primer yang meliputi: Peraturan Pemerintah No. 99 Tahun 2012 Tentang Syarat Dan Tata Cara Pelaksanaan Warga Binaan Permasyarakatan, Undang-Undang No. 12 Tahun 1995 Tentang Permasyarakatan, UUD 1945, Keppres No.174 Tahun 1999 Tentang Remisi Dan UU No. 12 Tahun 2011 Tentang Pembentukan Peraturan Perundang-Undangan.

Soekanto, Soerjono, dan Mamudji, Sri, 2006, "Penelitian Hukum Normatif Suatu Tinjauan Singkat”, PT. Raja Grafindo Persada, Jakarta hal.13 
2. Bahan hukum sekunder meliputi: bahan ini digunakan sebagai penjelas dari bahan hukum primer, dalam penelitian ini bahan hukum sekunder yang digunakan ialah hasil penelirtian hukum, hasil dari seminar, literatur yang berkaitan dengan obyek penelitian ini,makalah-makalah, jurnal hukum dan hasil karya ilmiah.

3. Bahan hukum tersier: bahan hukum yang akan memberikan penjelasan serta petunjuk yang berkaitan dengan bahan hukum primer dan bahan hukum sekunder seperti ensiklopedia hukum, kamus, serta lain sebagainya.

Dalam menghimpun data langkah-langkah yang perlu dilakukan yaitu menganalisa atau mempelajari segala literatur yang mempunyai kaitannya dengan obyek masalah yang terdapat dalam penelitian ini dan mengutip beberapa pernyataan dan pendapat yang disusun sistematis sebagai landasan untuk mendukung menjawab masalah pada penelitian ini.

Penelitian ini memakai teknik sistematisasi dan deskriptif dalam menganalisis permasalahan. Adapun pengertian dari teknik sistematisasi yaitu teknik yang mencari suatu keterkaitan rumusan yang ada dalam proposisi hukum antara peraturan hukum atau regulasi yang sebanding maupun antara peraturan perundangan yang tidak sejajar atau sebanding. Sedangkan artian dari teknik deskriptif yakni merupakan teknik yang menerangkan kondisi atau posisi yang terdapat dalam porsi-porsi hukum maupun non hukum atau diluar hukum secara apa adanya.

\section{Pembahasan}

\subsection{Syarat Pemberian Remisi Terhadap Pelaku Tindak Pidana Korupsi Yang Diatur Dalam PP No. 99 Tahun 2012 Yang Dihubungkan Dengan UU No. 12 Tahun 1995 Tentang Permasyarakatan}

Negara Indonesia merupakan negara hukum yang mana bisa dilihat dalam Pasal 1 ayat 3 UUD 1945 yang mana melindungi hak dari setiap warganya merupakan ciri dari suatu negara hukum. Perlindungan hukum yang diberikan oleh negara kepada warga negaranya tiak memandang perbedaan agama, ras, etnik, suku, status hukum hingga status sosial, semua individu diperlakukan sama dan pemenuhan hak kepada warganya 
negaranya tersebut. Setiap warga negara memiliki hak yang diperoleh dari negaranya termasuk hak yang mengacu pada status hukum warga negara tersebut. Meskipun status warga negara tersebut merupakan seorang terpidana negara tetaplah harus memberikan hak-haknya sebagai warga negara, negara tidak diperbolehkan membuat pengecualian dengan meniadakan hak narapidana melainkan haruslah melindungi hak tersebut tanpa terdapat pengecualian.

Remisi merupakan pengurangan hukuman yang diberikan oleh negara kepada narapidana yang telah memenuhi syarat tertentu,bisa dikatakan sebagai hak namun juga terdapat sebuah kewajiban. Remisi memiliki kaitan dengan Lembaga Permasyarakatan khususnya dengan narapidananya. Remisi berasal dari bahasa latin yaitu remissio yang memiliki arti pengurangan atau potongan dari hukuman. Sedangkan menurut pengertian umunya remisi merupakan pengurangan, pembebasan hukuman sebagian atau keseluruhan dari hukuman terbatas bahkan hukuman seumur hidup. ${ }^{4}$ Selain pengertian tersebut, Andi Hamzah menyatakan pendapatnya bahwa remisi merupakan pembebasan atau pengurangan hukuman baik sebagian atau seluruhnya menjadi hukuman tebatas dari hukuman seumur hidup yang diberikan setiap tanggal 17 Agustus. Dalam sistem permasyarakatan remisi berarti diskon atau potongan hukuman bagi narapidana setelah memenuhi syarat-syarat yang telah ditentukan.

Narapidana kehilangan hak kemerdekaannya, namun negara tetap memberikan hak sebagai warga negara dan tetap melindungi hak asasinya. Masih ada hak-hak dari narapidana yang dilindungi oleh sistem permasyarakatan Indonesia, hak-hak tersebut antara lain yaitu :

a. Hak untuk tetap melakukan kewajiban kepada Tuhan, yaitu beribadah;

b. Hak memperoleh perawatan jasmani maupun perawatan rohani;

c. Hak untuk memperoleh ilmu atau pendidikan;

d. Hak mendapatkan makanan yang layak untuk dimakan dan hak mendapatkan layanan kesehatan;

${ }^{4}$ Andi Hamzzah, "Kamus Hukum" 
e. Hak untuk mengeluarkan segala keluhannya;

f. Hak mendapatkan berita atau informasi;

g. Hak memperoleh gaji atau upah atas pekerjaannya;

h. Hak untuk menerima tamu kunjugan;

i. Hak memperoleh cuti sebelum bebas;

j. Hak guna memperoleh bebas bersyarat;

k. Hak memperoleh kesempatan untuk berbaur dengan orang lain termasuk keluarga;

1. Hak memperoleh remisi;

m. Dan hak-hak lainnya yang sesuai dengan regulasi. ${ }^{5}$

Dalam menjalankan hak-hak narapidana, kepada narapidana yang dijatuhi vonis hukuman seumur hidup pemerintah memberikan kesempatan kepada narapidana yang bersangkutan untuk memperbaiki diri dan memiliki harapan menjadi sosok yang lebih baik untuk hidup ditengah-tengah masyarakat sehingga masyarakat akan menerimanya kembali. Selain hal tersebut, tujuan dari remisi adalah kebijakan untuk menciptakan sistem permasyarakatan yang sesuai dengan Standar Minimum Rules. ${ }^{6}$

Disamping hak-hak yang telah dikemukakan tersebut, selama menjalani masa penjara narapidana juga memiliki beberapa kewajiban, kewajiban-kewajiban yang dimaksud yaitu:

1. Wajib ikut kegiatan pembinaan yang ada di lembaga permasyaratakatan;

2. Berkewajiban mematuhi segala peraturan ketetiban serta keamanan yang ada di Lapas;

3. Berkewajiban bekerjasama dengan petugas yang ada di Lapas

Tujuan diadakannya pemberian remisi dapat dilihat dalam Keputusan Presiden Republik Indonesia No. 174 Tahun 1999, yang mana tujuannya meliputi sebagai berikut :

Tunggal, Setia Hadi, 2000, "Undang-Undang Permasyarakatan", Haevarindo, Jakarta, Hal $7-8$

Arifin, Zainal,2012, "Tinjauan Hukum Islam Terhadap Pemberian Remisi Pada Narapidana", Skripsi, Hal. 62, Diakses Pada tanggal 16 Januari Pukul 04.00 WIB 
1. Sebagai simulasi dan motivator serta sebagai alat untuk mengingatkan narapidana agar selama berada di Lembaga Permasyarakatan selalu bersikap baik;

2. Guna usaha untuk mengurangi efek negatif dan subkultural tempat pelaksanaan pidana, disparitas pidana efek dari kemerdekaan yang dirampas. Jika dilihat dari psikologi, dengan memberikan remisi ini akan memberikan pengaruh menekan tingkat frustasi atau stress terutama untuk narapidana residivis. Sehingga dapat mengurangi atau bahkan mereduksi gangguan ketertiban atau keamanan di Rutan/LP, seperti melarikan diri atau bentuk kerusuhan lainnya;

3. Diharapkan remisi yang diberikan pada hari-hari tertentu seperti hari besar keagamaan bisa memicu narapidana menyadari diri atau bertobat sesuai dengan tuntutan agama masing-masing.

Sedangkan pemberian dan syarat diberikannya remisi terhadap narapidana menurut KeppresRI No. 174 Tahun 1999 diklasifikasikan menjadi tiga, antara lain sebagai berikut :

a. Remisi Umum, yang mana remisi ini diberikan pada hari-hari tertentu, seperti hari peringatan proklamasi pada tanggal 17 Agustus.

b. Remisi khusus, remisi ini diberikan kepada narapidana pada hari besar keagamaan yang dianut oleh terpidana, dan apabila dalam satu tahun terdapat hari besar lebih dari satu maka yang dipilih oleh narapidana yaitu hari besar yang paling dimuliakan oleh penganut agama yang bersangkutan.

c. Yang terakhir yaitu remisi tambahan, remisi ini diberikan kepada narapidana apabila selama menjalani hukuman narapidana melakukan jasa kepada negara, atau narapidana telah melakukan perbuatan yang berguna/bermanfaat bagi negara atau bagi orang lainnya, atau juga narapidana telah melakukan perbuatan yang membantu aktivitas pembinaan Di Lembaga Permasyarakatan.

Sedangkan besaran yang bisa didapat oleh narapidana, antara lain yaitu :

1. A. Besar dari remisi umum, yaitu : 
1. Satu bulan, apabila telah menjalani hukumannya selama 6-12 bulan;

2. Dua bulan, didapatkan oleh narapidana apabila narapidana telah menjalani hukuman selama 12 bulan atau lebih.

B. Syarat memperoleh remisi umum meliputi :

1. Merupakan warga binaan permasyarakatan yang sedang tidak cuti menjelang bebas dari hukuman;

2. Sedang tidak menjalani hukuman seumur hidup atau hukuman mati;

3. Narapidana sedang tidak menjalani pidana pengganti denda;

4. Tidak dijatuhi hukuman disiplin;

5. Telah menjalani hukuman selama lebih dari enam bulan.

C. Remisi Umum diberikan pada:

1. Remisi tahun pertama diberikan sebesar satu bulan bagi narapidana yang telah menjalani hukuman selama 6 sampai 12 bulan;

2. Kemudian diberikan remisi pada tahun kedua sebanyak tiga bulan;

3. Tahun berikutnya yaitu pada tahun ke tiga, narapidana diberikan remisi sebanyak empat bulan;

4. Kemudian akan diberikan remisi sebanyak lima bulan pada tahun ke empat dan ke lima;

5. Serta pada tahun ke enam dan selanjutnya narapidana akan diberikan remisi selama enam bulan pada setiap tahunnya.

2. A. Besar dari remisi kusus, meliputi :

1. Mendapatkan remisi sebesar lima belas hari apabila telah menjalani hukuman selama enam sampai dua belas bulan

2. Diberikan remisi sebesar satu bulan apabila telah menjalani hukuman dua belas bulan atau lebih

B. Syarat agar memperoleh remisi khusus yaitu :

1. Narapidana sedang tidak cuti karena mendekati hari bebas 
2. Tidak dijatuhi hukuman disiplin atau bebas dari hukuman disiplin

3. Sudah melewatimasa hukuman selama enam bulan atau lebih

4. Narapidana tidak sedang menjalani hukuman seumur hidup atau mati.

5. Narapidana tersebut tidak sedang menjalani pidana denda

C. Pelaksanaan remisi kusus sebagai :

1. Remisi akan diberikan selama lima belas hari pada tahun pertama apabila narapidana telah melaksanakan hukuman selama enam bulan

2. Remisi diberikan selama satu bulan yaitu pada tahun kedua dan ketiga

3. Remisi akan diberikan selama satu bulan lebih lima belas hari pada tahun ke empat dan kelima

4. Kemudian pada tahun ke enam dan tahun-tahun selanjutnya remisi diberikan sebanyak dua bulan dan diperoleh setiap tahun dua kali.

D. Pemberian Remisi Khusus Dilaksanakan Pada Hari-hari:

1. Pada Hari Raya Idul Fitri bagi Narapidana dan anak pidana yang menganut agama Islam.

2. Bagi Narapidana dan anak pidana yang beragama Kristen, maka dilaksanakan pada Hari Raya Natal

3. Dilaksanakan pada setiap Hari Raya Nyepi jika yang dianut adalah agama Hindu

4. Dan bagi Narapidana dan anak narapidana yang beragama Hindu maka pelaksanaan remisi kusus dilakukan pada Hari Raya Waisak.

Jika saat menjalankan hukuman diketahui narapidana melakukan pindah agama, maka remisi akan diberikan dan dilaksanakan pada agama yang dianut sesuai dengan pendataan waktu pertama kali dilakukan oleh petugas Lembaga Permasyarakatan.

A. Besar dari remisi tambahan yaitu : 
1. $1 / 2$ dari remisi umum yang didapatkan oleh narapidana pada tahun tersebut yang mana narapidana telah berbuat jasa terhadap negara atau pada manusia lainnya.

2. 1/3 dari remisi umum yang didapatkan oleh narapidana yang telah berjasa membantu aktifitas kegiatan pembinaan yang ada di lapas

B. Remisi tidak dapat diberikan kepada narapidana yang :

1. Melaksanakan hukuman penjara sebagai hukuman pengganti denda

2. Menjalani cuti karena mau bebas dari hukuman atau masa hukumannya mau habis

3. tercatat dalam pelanggaran tata tertib dan dijatuhi hukuman disiplin

4. masih menjalani hukuman kurang dari enam bulan

C. Sedangkan syarat agar mendapatkan remisi tambahan yaitu sebagai berikut :

1. Tidak sedang mau bebas sehingga menjalani cuti menjelang bebas

2. Tidak sedang melakukan hukuman pengganti denda

3. Tidak mendapatkan hukuman seumur hidup atau hukuman mati

4. Telah menjalani hukuman lebih dari enam bulan lamanya

5. Tidak dihukum hukuman kedisiplinan.

Masih terdapat bahasan mengenai remisi, yaitu Remisi Khusus yang bersyarat, Remisis Khusus yang tertunda, dan Remisi Tambahan. Remisiremisi tersebut diatur dalam Surat Edaran Direktorat Jenderal Permasyarakatan Nomor E.UM.01.10-130 Tahun 2001. Pada surat edaran tersebut dibahas mengenai :

a. Remisi Khusus Bersyarat

Remisi khusus merupakan remisi yang diberikan pada hari-hari besar keagamaan yang dianut oleh narapidana dan anak narapidana. Remisi khusus bersyarat ini merupakan remisi yang diusulkan jika narapidana dan anak pidana belum genap melaksanakan hukuman 
selama enam bulan dan memperlihatkan masa pidananya yang dihitung ketika masih pada tingkat penyidik dan tanggal pendataannya pada tingkat tersebut.

b. Remisi Khusus Tertunda

Remisi ini diberikan jika narapidana dan anak pidana telah memenuhi syarat substantif ketika hari besar keagamaan. Namun pada saat tersebut narapidana yang bersangkutan berada dalam status yang mana menyebabkan yang bersangkutan pada saat itu tidak berhak mendapatkan remisi. Kemudian remisi yang menjadi haknya akan diusulkan saat status narapidana yang bersangkutan telah mendapatkan kekuatan hukum yang mana telah dieksekusi oleh JPU.

Di Indonesia, pemberian remisi dilakukan dengan cara :

1. Dilakukan dengan cara bertahap, hal ini supaya pembinaan betulbetul dipahami dengan benar dan meresap pada jiwa narapidana sehingga diharapkan mampu menciptakan landasan moral yang baik. Pemahaman akan pemidanaan yang telah meresap kedalam jiwa diharapkan mampu untuk meredam keinginan untuk melakukan kejahatan kelak dimasa yang akan datang ketika narapidana telah keluar dari tahanan dan berbaur dengan masyarakat. Diharapkan pengalaman-pengalaman yang terjadi ketika narapidana masih menjalankan hukuman dapat dijadikan sebagai pelajaran yang sangat berharga, sehingga dengan diadakannya pemberian remisi secara bertahap ini diharapkan bisa mencapai sasaran yang mana menginginkan bagi pelaku kejahatan untuk merubah dirinya menjadi sosok yang lebih baik dengan didasari moral dan jiwa yang tenang lagi kokoh.

2. Sedangkan yang kedua adalah pemberian remisi secara bertingkat, hal tersebut ditujukan untuk memperlihatkan jika ketekunan dalam mentaati peraturan pemerintah melalui Lapas semakin baik. Selain itu diharapkan pada narapidana yang telah lama menjalani 
pembinaan supaya kesadarannya lebih baik daripada narapidana yang baru saja menjalani pemidanaan.

Bagi narapidana yang divonis dengan hukuman seumur hidup, maka syarat yang harus dipenuhi agar bisa mendapatkan remisi yakni dengan mengganti atau merubah menjadi hukuman pidana sementara yang awalnya adalah hukuman seumur hidup. Hal itu dapat dilihat dalam Pasal 9 ayat 1-4 Keppres No.174 Tahun 1999 Tentang Remisi yang mana menyebutkan antara lain sebagai berikut :

1. Narapidana yang bersangkutan harus mengajukan permohonan mengenai penjara seumur hidup menjadi pidana penjara sementara kepada Presiden RI lewat Menteri Hukum Dan Perundang-undangan;

2. Syarat narapidana yang berhak mengajukan permohonan hukuman sementara yaitu bahwa narapidana yang bersangkutan telah menjalani hukuman paling sedikit lima berturut-turut dengan lama hukuman penjara 15 tahun serta narapidana harus memiliki catatan berperilaku baik;

3. Tata cara permohonan untuk merubah dari hukuman pidana penjara seumur hidup menjadi hukuman pidana sementara lebih detail diatur oleh Keputusan Menteri Hukum Dan Perundang-Undangan;

4. Presidenlah yang menetapkan perubahann atas pidana penjara seumur hidup menjadi hukuman pidana sementara.

Remisi atau bisa disebut juga sebagai pengurangan hukuman merupakan hak bagi narapidana, hak tersebut diatur dalam UU Tentang Permasyarakatan kususnya terdapat dalam Pasal 14 ayat (1) huruf i. Remisi bisa didapatkan oleh semua narapidana tanpa pengecualian selama narapidana tersebut memenuhi syarat-syarat yang telah diberikan untuk menerima remisi, syarat-syarat tersebut diatur pada Pasal 34 Peraturan Pemerintah No. 99 Tahun 2012 dan Pasal 34A ayat (1) huruf a dan b mengatur mengenai remisi bagi narapidana tindak kejahatan korupsi. Dengan adanya peraturan remisi bagi narapidana korupsi yang diatur berbeda atau diatur tersendiri bukanlah untuk mendiskriminasikan kejahatan tersebut melainkan ditujukan untuk mengimbangkan jenis kejahatan yang 
ada, sudah menjadi kesepakatan umum bahwa kejahatan korupsi merupakan kejahatan yang luar biasa atau extra ordinary yang berdampak besar pula pada negara, keuangan negara, dan masyarakat. Sehingga wajar apabila terdapat pengaturan sendiri mengenai kejahatan korupsi mengingat kejahatan tersebut merupakan masalah terbesar di negara ini yang sulit untuk diberantas.

Dengan begitu syarat penerimaan remisi diperketat dalam PP No. 99 Tahun 2012 memanglah wajar guna mencegah narapidana korupsi untuk bebas dengan mudah. Sebenarnya apabila dilihat lebih lanjut dengan sudut pandang hierarki peraturan perundang-undangan yang ada di Indonesia, pembuatan PP No. 99 Tahun 2012 tidaklah melihat aturan mengenai pembuatan Undang-Undang yang terdapat pada UU No. 12 Tahun 2011 Tentang Pembetukan Peraturan Perundang-Undangan. Hal ini diungkapkan karena melihat aturan yang ada dalam PP tersebut bertentangan UU No.12 Tahun 1995 Tentang Permasyarakatan. Sehingga antara kedua pengaturan tersebut terdapat kontradiksi yang mana peraturan yang lebih rendah tidak sejalan atau tidak megikuti peraturan yang lebih tinggi,padahal seharusnya pengaturan tersebut haruslah sejalan.

Mengenai pemberian remisi, cuti menjelang hukuman yang hampir selesai atau menjelang bebas, asimilasi, serta pembebasan bersyarat terhadap narapidana yang dihukum akibat dari melakukan kejahatankejahatan khusus seperti menggunakan narkoba, terorisme, kejahatan yang mengancam keamanan negara, kejahatan berat terhadap hak asasi manusia, kejahatan transnasional, dan kejahatan korupsi haruslah diberikan syarat yang tinggi dalam pemberian remisi mengingat haruslah menyesuaikan pada dinamika dan rasa keadilan masyarakat, oleh sebab itu perlunya memberikan batasan-batasan dalam pemberian remisi terhadap kejahatankejahatan khusus tersebut, yang mana dimaksudkan sebagai berikut:

1. Ketentuan aturan hukum tersebut hanya berlaku pada bandar dan prodesen apabila kejahatannya masuk dalam kategori penggunaan narkoba dan psikotropika. 
2. Dalam kejahatan tindak pidana korupsi, aturan dari pemerintah ini hanya berlaku pada narapidana yang masuk dalam kriteria :

a. Merugikan uang dengan paling sedikit sebesar 1 Milyar

b. Menjadi sorotan perhatian dan meresahkan masyarakat

c. Korupsi tersebut dilakukan oleh penyelenggara negara, aparat penegak hukum, dan pihak lain yang memiliki kaitan dengan korupsi yang telah dilakukan oleh pejabat negara dan aparat penegak hukum tersebut.

Peraturan mengenai remisi yang terdapat dalam PP No. 99 Tahun 2012 dipandang telah bertentangan dengan UU No. 12 Tahun 1995 Tentang Permasyarakatan, kususnya pada Pasal 34A ayat (1) yang bertentangan dengan Pasal 5 UU No. 12 Tahun 1995 Tentang Permasyarakatan yang mana pokok dari isinya melarang adanya perbedaan pelayanan atau perlakuan terhadap narapidana yang berarti bahwa seluruh narapidana diberlakukan sama tanpa adanya unsur deskriminasi. Tak hanya itu, ditemukan terdapat perbedaan pula yang ada pada Pasal 34A ayat (1) huruf a dan b yang bertentangan pada Pasal 28 D ayat (1) UUD NRI Tahun 1945 yang bahwasanya menurut pasal 28 tersebut setiap orang memiliki hak atas jaminan, pengakuan, perlindungan, perlakuan yang sama dimata hukum, serta hak mendapatkan kepastian hukum yang adil.

Pengetatan dalam pemberian remisi juga ditemukan telah bertentangan dengan Pasal 28 J UUD 1945 yang menyebutkan :

1. Setiap orang dalam berkehidupan bermasyarakat, berbangsa dan bernegara haruslah saling menghargai danmenghormati hak asasi orang lainnya.

2. Setiap orang berkewajiban mematuhi pembatasan yang diatur dalam UU dengan tujuan agar menjamin penghormatan dan pengakuan kebebasandan hak orang lain serta untuk menjalankan tuntutan yang adil sesuai dengan nilai-nilai agama, keamanan, moral, dan ketertiban umum dalam masyarakat yang demokratis.

Hal ini dapat disimpulkan bahwa dilarangnya pembatasan hak asasi manusia apalagi jika pengaturannya ada dalam ketentuan Peraturan 
Pemerintah, kalaupun pada akhirnya dikehendaki adanya suatu pembatasan maka seharusnya diatur dalam UU bukannya PP karena pada Pasal 28 tersebut mengatur secara tegas bahwa pembatasan hak asasi manusia tidaklah boleh diatur dalam pengaturan dibawah undang-undang yang otomatis harusnya aturan terseut dibuat dalam suatu Undang-Undang, bukan Peraturan Pemerintah.

Syarat pengetatan dalam pemberian remisi pada PP No. 99 Tahun 2012 jika tidak segera dirubah maka akan terus dinyatakan bertentangan dengan UUD 1945 serta UU Tentang Permasyarakatan. Karena telah melanggar hierarki peraturan perundangan. UU Tentang Permasyarakatan juga dinilai telah bertentangan dengan UUD 1945 dikarenakan dalam melakukan pembatasan hak asasi terhadap narapidana haruslah diatur lebih rinci pula mengenai hak remisi narapidana kasus korupsi sehingga uu tersebut tidak hanya mengatur mengenai syarat pemberian remisi yang diperketat. $^{7}$

Oleh sebab itu jika ada pembatasan syarat pemberian remisi maka hak remisi terhadap narapidana yang terdapat dalam UU tentang Permasyarakatan juga haruslah dibenahi klausal aturannya sehingga terjadi keselarasan antara UU Permasyarakatan yang mengatur mengenai hak remisi dengan PP yang mengatur mengenai syarat-syarat yang harus terpenuhi bagi narapidana jika ingin memperoleh remisi.

\subsection{Pemberian Remisi Yang Diatur Dalam PP No. 99 Tahun 2012 Dikaitkan Dengan Teori Tujuan Pemidanaan.}

Terdapat tiga teori dasar pidana yang setidkanya dikenal memberikan gambaran tentang tujuan pemidanaan, teori-teori tersebut antara lain yaitu teori relatif, abdolut, serta teori gabungan. ${ }^{8}$ Akan tetapi pada realitanya tidak ada satupun dari teori tersebut yang digunakan secara mutlak. Sehingga dengan seiring perkembangan jaman, tujuan pemidanaan lebih dipokokkan

Madji Abdul, dan Harjati Eny, "Analisis Yuridis Kedudukan Peraturan Pemerintah Nomor 99 Tahun 2012 Terhadap Kebijakan Pengetatan Pemberian Remisi Bagi Narapidana Korupsi Sebagai Bentuk Penanggulangan Tindak Pidana Korupsi Di Indonesia”, Analisis Ilmiah FH. UB, Hal. 8

Anwar Yesmil, Adang, 2008, "Pembaruan Hukum Pidana:Reformasi Hukum", Grasindo, Jakarta, Hal. 137-138 
antara lain yaitu bertujuan guna memperbaiki kepribadian dari penjahat itu sendiri, membuat pelaku kejahatan jera atas tindakannya, membuat agar pelaku kejahatan tertentu berhenti atau agar tidak melakukan tindak kejahatan tertentu lagi, ${ }^{9}$ dan memberikan deterrence effect atau efek jera pada pelaku tindak kejahatan. ${ }^{10}$

Tujuan dari pemidanaan sebenarnya bisa tercapai dengan mengatur para narapidana sesuai dengan sifat dan karkter masing-masing dari tindak pidana. Pada masalah ini, telah dibahas bahwa kejahatan korupsi merupakan kejahatan luar biasa yang dalam artian bahwa penanganannya juga memerlukan upaya yang besar agar tujuan pemidanaan bisa terwujud. Akan tetapi hal tersebut hanya akan jadi khayalan saja jika negara tidak dengan tegas membuat pengaturan kusus mengenai remisi korupsi. Remisi merupakan pengurangan hukuman yang diberikan kepada narapidana atau bisa disebut juga dengan "Diskon". ${ }^{11}$

Dalam kaitannya dengan syarat pemberian remisi yang diatur dalam Pasal 34 (A) PP No. 99 Tahun 2012 Tentang syarat dan Tata Cara Pelaksanaan Hak Warga Binaan Permayarakatan yang ditarik kaitannya dengan teori tujuan pemidanan maka akan menemukan dua pendapat atau pemikiran yang berseberangan. Yang pertama, mengenai pemberian remisi yang dikaitkan dengan teori relatif,yang dalam hal ini mengfokuskan mengenai tujuan pemidanaan untuk merubah sifat atau memperbaiki pelakui kejahatan. Hal ini bertujuan agar dengan adanya suatu pemidanaan diharapkan bahwa kelak pelaku kejahatan tersebut dan berubah menjadi orang atau pribadi yang lebih baik dan untuk memperbaiki keseimbangan yang telah rusak akibat dari kejahatan yang telah dilakukan. Dahulu sebelum tahun 1964 konsep dari tujuan pemidanaan adalah sebuah konsep balas dendam, namun sejak tahun tersebut muncul system kepenjaraan yang

Asmarawati, Tina, 2015, "Pidana Dan Pemidanaan Dalam Sistem Hukum di Indonesia (Hukum Penitensier)". Deepublish, Yogyakarta, Hal. 82

Isra, Saldi, 2009, “Catatan Hukum Saldi Isra Kekuasaan Dan Perilaku Korupsi”, Penerbit Buku Kompas, Jakarta, Hal. 60

Redaksi RAS, 2010, “TIP Hukum Praktiks:Menghadapi Kasus Pidana”, Raih Asa Sukses, Depok, Hal. 165 
baru dan dikenal dengan system permasyarakatan. ${ }^{12}$ Pokok dari teori tersebut telah diadopsi dalam sistem permasyarakatan di Indonesia yang mana dapat dilihat pada huruf (c) UU Permasyarakatan, yang pokok dari isinya yaitu mengenai sistem permasyarakatan yang dimaksudkan dalam hruruf $\mathrm{b}$ merupakan serangkaian penegakan hukum yang memiliki tujuan supaya warga binaan permasyarakatan mengakui dan menyadari bahwa perbuatan yang dilakukannya adalah merupakan kesalahan, supaya memperbaiki diri, dan agar narapidana tidak mengulangi tindak kejahatan sehinga nanti apabila telah terbebas dari masa hukuman bisa diterima kembali oleh masyarakat, bisa aktif berperan dalam pembangunan negara, serta agar bisa hidup normal sebagai warga negara.

Remisi bukanlah suatu hukum dalam system permasyarakatan, bukan pula sebagai berkah dalam sistem kepenjaraan, melainkan sebagai sebuah hak dan kewajiban yang dipunyai oleh narapidana. Dalam artian apabila narapidana telah melakukan kewajibannya dengan baik maka ia berhak untuk memperoleh remisi. ${ }^{13}$

Sedangkan yang kedua, berpendapat mengenai syarat-syarat kusus yang harus terpenuhi oleh narapidana jika ingin mendapatkan remisi, bahwa dengan adanya syarat apapun yang hendak dijadikan dasar dari pemberian remisi hanya akan memperlambat tujuan dari pemidanaan. Berpendapat demikian karena biar dipandang dari segi manapun korupsi adalah kejahatan serius yang membuat negara mengalami kerugian yang sangat besar sehinga dengan adanya remisi yang diberikan dapat mempercepat seorang koruptor keluar dari lembaga permasyarakatan, sehingga tidak sepadan dengan kejahatan yang telah dilakukannya. Dengan adanya remisi para koruptor tidak akan terlalu cemas akan hukuman penjara karena koruptor akan bisa mempercepat keluar dari hukuman, dan jika dihitung secara ekonomis dengan menggabungkan uang hasil korupsi dan hukuman tahanannya pasti tetap mendapatkan keuntungan. Belum lagi pada masa ini sistem lembaga

Atmasasmita,Romli, 1975, "Dari Pemenjaraan Ke Pembinaan Narapidana", Alumni, Bandung, hal. 72

Harsono, cL, 1995, "Sistem Baru Pemidanaan Narapidana”, Djambatan, Jakarta Hal. 25 
permasyarakatan dinilai terlalu memanjakan para terpidana korupsi dengan memberikan fasilitas layaknya hotel berbintang. ${ }^{14}$

Sehingga pada akhirnya, vonis yang dijatuhkan oleh hakim kepada tepidana korupsi tidak akan pernah tepat sasaran, sebab tujuan pemidanaan mengenai efek jera kepada para tindak pidana kejahatan korupsi tidak akan pernah tercapai, koruptor tidak akan pernah jera dengan perbuatan yang dilakukannya. Hal ini juga mempengaruhi calon para koruptor untuk menjadikan remisis sebagai alat, dengan adanya remisi maka peluang untuk bebas dari tahanan bisa dipercepat sehingga para calon koruptor tidak ragu untuk melakukan korupsi dengan mempertimbangkan atau menghitung keuntungan yang dia dapat. ${ }^{15}$ Dengan hal seperti itu sehingga ditakutkan korupsi akan semakin meningkat dan sulit untuk dibendung. Perlu digaris bawahi bahwa penolakan pemberian remisi terhadap terpidana korupsi bukan merupakan bentuk pelanggaran terhadap hak narapidana akan tetapi yang perlu dilakukan seharusnya adalah memberikan standar lebih tinggi kepada terpidana korupsi dalam mendapatkan remisi hal ini dianggap sebagai cara untuk menangani masalah tindak pidana korupsi.

\section{Kesimpulan}

Kesimpulan yang bisa diambil dari pembahasan diatas yaitu :

1. Syarat pemberian remisi yang diatur dalam PP. No 99 Tahun 2012 Tentang Syarat Dan Tata Cara Pelaksanan Hak Warga Binaan Permasyarakatan bertentangan dengan aturan yang terdapat dalam UU No. 12 Tahun 1995, Kususnya dalam pasal 34A ayat (1) PP No. 99 Tahun 2012 yang bertentangan dengan Pasal 5 UU No. 12 Tahun 1995 Tentang permasyarakatan yang mana melarang adanya perbedaan pelayanan dan perlakuan terhadap narapidana yang berarti bahwa semua narapidana harus diberlakukan sama tanpa adanya deskriminasi. Selain itu, jika dilihat dengan sudut pandang hierarki perundang-undangan terdapat

14 Indrayana, Denny, 2008, "Negeri Para Mafioso Hukum Di Sarang Koruptor”, Penerbit Buku Kompas. Jakarta, Hal. 77

15 Hutauruk, Alfred, Hutauruk, Maulan, 1961, "Garis Besar Tata Hukum Indonesia", Erlangga, Jakarta, Hal. 68 
ketidaksinambungan antara kedua peraturan tersebut, seharusnya aturan yang posisinya lebih rendah harus mengikuti atau tunduk pada peraturan peraturan yang ada diatasnya atau dengan kata lain terdapat kontradiksi antara peraturan yang lebih tinggi dengan peraturan yang lebih rendah, sehingga dipastikan dalam pembuatan PP tersebut tidaklah melihat peraturan perundang-undangan yang diatur pada Pasal 7 UU No. 12 Tahun 2011 Tentang Pembentukan Peraturan Perundang-Undangan. Negara bisa membuat kebijakan mengenai syarat pemberian remisi terhadap narapidana melainkan tidak dalam Peraturan Pemerintah, namun dalam bentuk Undang-Undang

2. Pemberian remisi yang diatur dalam PP No. 99 Tahun 2012 kemudian dikaitkan dengan teori tujuan pemidanaan memiliki dua pendapat yang berbeda. Pendapat pertama menyatakan bahwa dengan diberikannya remisi pada narapidana tindak pidana korupsi memanglah wajar, dikarenakan remisi bukanlah suatu hukum dalamsistem permasyarakatan dan bukan sebagai berkah dalam sistem kepenjaraan, namun melainkan sebagai hak dan kewajiban bagi narapidana sendiri yang mana narapidana berhak mendapatkan remisi apabila telah memenuhi semua kewajiban dan syarat-syarat yang telah ditentukan, dan biar bagaimanapun narapidana masihlah seorang manusia yang memiliki hak asasi manusia yang tidak boleh di deskriminasikan. Sedangkan pendapat kedua menyebutkan bahwa kejahatan korupsi merupakan kejahatan luar biasa yang mana penanganannya juga diperlukan upaya yang lebih besar sehingga dengan pemberian remisi terhadap koruptor dikhawatirkan dijadikan alat untuk keluar dari hukuman lebih cepat dan dikhawatirkan pula menghilangkan efek jera padahal tujuan dari teori pemidanaan yaitu memberikan efek jera supaya pelaku kejahatan berubah menjadi pribadi yang lebih baik dan tidak mengulangi melakukan tindak kejahatan. 


\section{DAFTAR PUSTAKA}

\section{Buku}

Anwar Yesmil, Adang, 2008, "Pembaruan Hukum Pidana:Reformasi Hukum", Grasindo,Jakarta Hal.137-138

Adami, hazawi, 2016, "Hukum Pidana Korupsi Di Indonesia", Jakarta, PT.Rajagrafindo Persada

Asmarawati, Tina,2015, "Pidana Dan Pemidanaan Dalam Sistem Hukum Di Indonesia (Hukum Penitensier)", Deepublish, Yogyakarta, Hal.82

Atmasasmita, Romli, 1975, "Dari Pemenjaraan Ke Pembinaan Narapidana", Alumni, Bandung, Hal. 72

Danil, Elwi, 2011, “Korupsi:Konsep, Tindak Pidana, Dan Pemberantasannya", Jakarta:PT. Raja Grafindo Persada

Hutauruk Alfred, Hutauruk Maulan, 1961, “Garis Besar Tata Hukum Indonesia”, Erlangga, Jakarta, Hal 68

Lilik, Mulyadi, 2007, “Tindak Pidana Korupsi Di Indonesia, Normatif, Teoritis, Praktik Dan Masalahnya”, Bandung PT.Alumni

Indrayana, Denny, 2008, "Negeri Para Mafioso Hukum Di Sarang Koruptor", Penerbit Buku Kompas, Jakarta, Hal 77

Isra, Saldi, 2009, “Catatan Hukum Saldi Isra Kekuasaan Dan Perilaku Korupsi”, Penerbit Buku Kompas, Jakarta, Hal. 60 
Madji Abdul, Dan Harjati Eny, “Analisis Yuridis Kedudukan Peraturan Pemerintah Nomor 99 Tahun 2012 Terhadap Kebijakan Pengetatan Pemberian Remisi Bagi Narapidana Korupsi Sebagai Bentuk Penanggulangan Tindak Pidana Korupsi Di Indonesia", Analisis Ilmiah FH. UB, Hal. 8

Marfin, M Nurul, 2012, “Korupsi Dalam Hukum Pidana Islam”, Pena Grafika, Jakarta, Hal 4

Rdaksi RAS, 2010, “TIP Hukum Praktiks:Menghadapi Kasus Pidana”, Raih Asa Sukses, Dpok, Hal. 165

Soerjono, Soekanto, dan Mamudji, Sri, 200, "Penelitian Hukum Normatif Suatu Tinjauan Singkat”, PT. Raja GrafindoPersada, Jakarta, Hal 13

Tunggal, Setia Hadi, 2000, "Undang-Undang Permasyarakatan", Haevarindo, Jakarta, Hal 7-8

Zainal, Arifin, 2012, “Tinjauan Hukum Islam Terhadap Pemberian Remisi Pada Narapidana”, Sripsi, Hal 62, Diakses pada tanggal 16 Januari Pukul 04.00 WIB

\section{Jurnal}

Arsyad, Sanusi, “Relasi Antara Korupsi Dan Kekuasaan”, Jurnal Konstitusi,Vol. 6 No. 2

Citrawan, Harison, 2011, “Dua Dimensi Remisi” Jurnal Ilmu Hukum HUMANIS, Vol. 2

Dwija, Priyanto, 2013, “Sistem Pelaksanaan Pidana Penjara Di Indonesia” Isra, Saldi, 2014, "Peran Mahkamah Konstitusi Dalam Penguatan Hak Asasi Manusia Di Indonesia”, Jurnal Konstitusi, Vo.11 No. 3

Nur, Hilman, "Penghapusan Remisi Bagi Para Koruptor Dalam Prespektif Undang-Undang No. 12 Tahun 1995 Tentang Permasyarakatan”, Jurnal Mimbar Justitia, Vo. 1 No. 2

Simarmata, Berlian, 2011, "Pemberian Remisi Terhadap Narapidana Koruptor Dan Teroris” Jurnal Ilmu Hukum Mimbar Hukum, Vo. 23 No. 3 


\section{Perundang-Undangan}

Peraturan Pemerintah No. 99 Tahun 2012 Tentang Syarat Dan Tata Cara Pelaksanaan Warga Binaan Permasyarakatan

UUD 1945

Undang-Undang No. 12 Tahun 1995 Tentang Permasyarakatan

Undang-Undang No. 12 Tahun 2011 Tentang Pembentukan Peraturan Perundang-Undangan

Keppres No.174 Tahun 1999 Tentang Remisi

\section{Internet}

Anonim, "Pengertian Dan Jenis Remisi", URL : http://www.gresnews.com/mobile/berita/tips/101170-pengertian-danjenisremisi/ , diakses pada tanggal 16 Januari 2020, Pukul 05.00 WIB

Ayu Pamesti, Tri Jata, 2018, "Prosedur Pemberian Remisi" , URL: https://m.hukumonline.com/klinik/detail/cl1425/prosedur-pemberianremisi/, diakses pada tanggal 16 Januari 2020,Pukul 05.15 WIB

Hendratno, Edie Toet, 2016, "Kebijakan Pemberian Remisi Bagi Koruptor, Suatu Telaah Kritis Dari Prespektif Sosiologi Hukum" URL: https://www.researchgate.net/publication/301740746_Kebijakan_Pember ian_Remisi_Bagi_Koruptor_Suatu_Telaah_Kritis_Dari_Prespektif_Sosio logi_Hukum, Diakses pada tanggal 16 Januari 2020, Pukul 05.40 WIB 